\title{
KOOPERENCJA MAŁYCH FIRM WOBEC GLOBALIZACJI GOSPODARKI
}

\author{
Edward Chrzan, Izabella Sowier-Kasprzyk \\ Politechnika Częstochowska \\ Wydział Zarządzania
}

\begin{abstract}
Streszczenie: Poglądy głoszące naturalną wyższość rywalizacji nad współpracą mają ponoć być zgodne z teorią darwinizmu społecznego. Współpraca, czyli umiejętność zespołowego wykonywania zadań i wspólnego rozwiązywania problemów, oznacza zdolność tworzenia więzi i współdziałania z innymi, umiejętność pracy w grupie na rzecz osiągania wspólnych celów. W nowoczesnej gospodarce możliwe jest zarówno konkurowanie, jak i współpraca przedsiębiorstw działających w tym samym sektorze rynku, czyli kooperencja. W warunkach globalizacji kooperencja jest szczególnie istotna dla małych przedsiębiorstw.

Celem niniejszego opracowania jest wskazanie możliwości współpracy na konkurencyjnym rynku (kooperencji) oraz określenie skali tego zjawiska wśród polskich małych przedsiębiorstw. Badanie pokazuje, że polscy przedsiębiorcy działający w tym samym (konkurencyjnym) sektorze rynku nie są szczególnie skłonni do współpracy.
\end{abstract}

Słowa kluczowe: globalizacja, kooperencja, small business

DOI: $10.17512 /$ znpcz.2017.4.2.02

\section{Wprowadzenie}

Współcześni propagatorzy i badacze gospodarki kapitalistycznej, wolnego rynku i w ogóle wywodzących się od Adama Smitha zasad ekonomii twierdzą, że ustrój wolnorynkowy z konkurencją jako jego głównym motorem jest po prostu zgodny z naturą ludzką. Konkurowanie, rywalizacja jest ponoć immanentną cechą każdej ludzkiej jednostki „prawem natury” zobowiązanej do dbania o własne dobro, do powiększania swoich zasobów. Zatem poglądy, które przeciwstawiają się takiej postawie, stawiają na egalitaryzm, są podobno sprzeczne $\mathrm{z}$ naturą ludzką. Tymczasem można z powodzeniem twierdzić, że jest wprost przeciwnie. Badania prowadzone przez antropologów pokazują, że to właśnie twarda konkurencja (wyścig szczurów) jest sprzeczna z naturą ludzką, jest więc swego rodzaju wynaturzeniem.

Kooperencja przedsiębiorstw jest specyficznym zjawiskiem w relacjach między przedsiębiorstwami, charakteryzującym się szerokim zbiorem przyjmowanych form, typów oraz poziomów występowania. Ważne jest zwrócenie uwagi na czynniki zewnętrzne i wewnętrzne istotne dla tworzenia oraz stabilności kooperencji przedsiębiorstw. Relacje kooperencyjne należą do najbardziej złożonych form rozwoju przedsiębiorstw i obarczonych znacznym ryzykiem. Powstaje zatem kwestia okoliczności, które skłaniają konkurentów do jednoczesnej rywalizacji 
i współdziałania. Brane są więc pod uwagę czynniki sektorowe oraz korporacyjne, mające duży wpływ na podjęcie decyzji przedsiębiorstw o kooperencji (Cygler 2009).

Celem niniejszego opracowania jest wskazanie możliwości współpracy na konkurencyjnym rynku (kooperencji) oraz określenie skali tego zjawiska wśród polskich małych przedsiębiorstw. Przeprowadzone badanie na grupie małych przedsiębiorstw mających swe siedziby głównie w zachodniej Małopolsce (od Częstochowy po Zagłębie Dąbrowskie) wykazuje ograniczoną skłonność ich właścicieli do podejmowania współpracy $\mathrm{z}$ innymi firmami działającymi w tym samym sektorze rynku.

\section{Wspólpraca a konkurencja w warunkach gospodarki rynkowej}

Poglądy głoszące naturalną wyższość rywalizacji nad współpracą mają ponoć być zgodne z teorią darwinizmu społecznego. Według tej teorii życie społeczne opiera się na walce między jednostkami, rasami czy narodami w podobny sposób, jak ujmuje to teoria ewolucji Darwina. Darwinizm społeczny zakłada, iż rozwój następuje od form społecznych bardziej prymitywnych do znajdujących się na wyższym poziomie. Sumner ${ }^{1}$ twierdził, że prawa natury obowiązują też w społeczeństwie i faktu tego nie da się zmienić żadnymi przepisami (prawem ustanawianym przez władze, dekretami itp.). W wyniku uczciwej (sic!) konkurencji najlepiej przystosowani, najskuteczniej przyswajający bogactwa przyrody i oferujący je innym ludziom będą osiągali sukces, a ludzie nieskuteczni i leniwi będą skazani na biedę.

Silniejszy wygra, słaby ulegnie. W wyobrażeniu wielu ludzi tak właśnie wygląda świat natury oraz tak właśnie zachowywał się człowiek pierwotny. Nie jest to prawdą. Naturalnie takie zachowania mimo wszystko dość często się zdarzają, a w związku z tym są spotykane. Nie stanowią one jednak reguły. Wręcz przeciwnie - poza niektórymi gatunkami zwierząt - są one odstępstwami od natury. To współpraca dla wspólnego dobra jest naturalnym czynnikiem rozwoju i tylko wtedy dany gatunek może zwiększyć swoją populację.

Tak zresztą myślał i sam Karol Darwin: „Słabość fizyczna i niezdolność do szybkiego biegania, a także brak broni naturalnej są u człowieka więcej niż zrównoważone po pierwsze przez jego zdolności umysłowe, i po wtóre przez ludzkie właściwości społeczne zapewniające człowiekowi pomoc towarzyszy" (Kropotkin 2006, s. 74). Jak pokazują badania antropologów, u ludów pierwotnych, nazywanych pogardliwie dzikimi, życie odbywało się najczęściej w tzw. komunizmie pierwotnym - bez państwa, bez ośrodków władzy, bez własności, w oparciu o zasady równości, wzajemnej pomocy i współpracy dla wspólnego zaspokajania potrzeb, nie tylko wspólnych, ale i poszczególnych osobników.

Sam Darwin, który oparł swą teorię ewolucjonizmu na konkurencyjności, na naturalnym doborze, na wypieraniu jednostek i gatunków gorzej przystosowanych

\footnotetext{
${ }^{1}$ William Graham Sumner (1840-1910), amerykański socjolog, profesor Uniwersytetu Yale, „ojciec” darwinizmu społecznego.
} 
przez jednostki lepiej sobie radzące w środowisku, miał wiele wątpliwości. Nie rozumiał do końca, dlaczego organizmy $\mathrm{w}$ danym środowisku zamiast walczyć o swój byt, wypierać inne organizmy, współpracują dla dobra większych grup, choć jest to często nawet wbrew ich jednostkowym interesom. Karol Darwin w swoim wiekopomnym dziele $O$ powstawaniu gatunków, wydanym w 1859 roku, pisze, że pewne zachowania obserwowane u owadów społecznych to szczególna trudność, która wydaje mu się nieprzezwyciężona i zadająca cios całej jego teorii. Dopiero w latach 60. XX wieku wybitny biolog - William Hamilton sformułował teorię doboru krewniaczego (ang. kin selection). Rozwiązywała ona problem Darwina, umacniając jego znakomitą skądinąd teorię. Zachowania robotnic jawiły się twórcy ewolucjonizmu jako niezrozumiały altruizm. Teoria Hamiltona zamieniła altruizm we współpracę (Panczykowski b.r.).

Rozwój cywilizacji, a można nawet powiedzieć rozwój człowieka jako gatunku homo sapiens, mógł nastąpić jedynie dzięki współpracy. Do dziś naukowcy nie są zgodni w ustaleniu daty pojawienia się człowieka na Ziemi. Na pewno było to ponad 10 milionów lat temu, a człowiek współczesny wykształcił się prawdopodobnie około 40 tys. lat temu. Jak by zresztą nie liczyć, to większość czasu kształtowania się gatunku ludzkiego, aż do momentu pojawienia się społeczności zorganizowanej na systemach wartości, które obowiązują współcześnie, przebiegał w swoistym komunizmie pierwotnym. Zresztą część z takich społeczeństw dotrwała w niektórych zakątkach świata nawet do XX wieku. W społeczeństwach pierwotnych panował ustrój egalitarny, $\mathrm{z}$ równym podziałem łupów w małych grupach łowieckich i zbierackich. W tych grupach nie było żadnych zróżnicowań społecznych, indywidualnego bogacenia się; kładziono nacisk na współpracę. I w tym „naturalnym” ustroju rozegrał się cały proces ewolucji. Krótko mówiąc, natura człowieka i jego byt w przytłaczającej większości jego czasu na Ziemi, związane były raczej ze współpracą niż z rywalizacją.

Niemniej jednak rywalizacja, konkurowanie, współzawodnictwo to zjawisko znane od zarania dziejów cywilizacji. Wtedy, kiedy człowiek zaczął być istotą osiadłą, rolnikiem, hodowcą, kiedy po raz pierwszy w dziejach wytworzył i posiadał nadwyżki żywności, powstała chęć do indywidualnego bogacenia się. Zaczęła kształtować się specjalizacja pracy, zróżnicowania społeczne. Człowiek jako rzemieślnik, twórca, organizator posiadający różne zdolności do wytworzenia wartości dodanej, otworzył nowy - trwający do dziś - rozdział w dziejach ludzkości. Ale ten ostatni rozdział zapoczątkowany został stosunkowo niedawno, zaledwie jakieś 10 tys. lat temu.

Akumulacja kapitału, jaka następowała w drodze konkurowania i stopniowego powiększania majątku poszczególnych jednostek, rodów lub ich grup, pozwalała na lepsze wykorzystanie tak zasobów materialnych, jak i pracy oraz zdolności ludzkich. Jak by zatem nie patrzeć, nie jesteśmy dziś w stanie uciec od konieczności konkurowania. Ale nie da się w tej narastającej konkurencji wszystkich ze wszystkimi i o wszystko uciec jednocześnie od współpracy. Paradoksalnie uczenie się konkurowania wymaga uczenia się współpracy.

Współpraca, czyli umiejętność zespołowego wykonywania zadań i wspólnego rozwiązywania problemów, oznacza zdolność tworzenia więzi i współdziałania 
$\mathrm{z}$ innymi, umiejętność pracy $\mathrm{w}$ grupie na rzecz osiągania wspólnych celów. Umiejętność współpracy stanowi jeden $\mathrm{z}$ wyróżników zachowań społecznych, które warunkują jakość relacji z innymi ludźmi. Zazwyczaj pojęcie współpracy kojarzy się z dwoma osobami czy organizacjami, wykonującymi różne - uzupełniające się - czynności. Należy jednak pamiętać, że współpracować może ze sobą dowolna liczba podmiotów, a wykonywane przez nie czynności, nie zawsze muszą być różne. Firmy współpracujące ze sobą na zasadzie outsourcingu będą w oczywisty sposób uzupełniały się $\mathrm{w}$ wykonywaniu odrębnych czynności tworzących określony proces. Żadna $\mathrm{z}$ tych stron nie ma na ogół umiejętności do wykonania czynności prowadzonej przez drugą ze stron, dlatego też muszą się one uzupełniać, aby cel dający zadowolenie każdej z nich mógł być w ogóle osiągnięty. Z drugiej strony możemy też mówić o współpracy wielu robotników niosących przedmiot o wielkim ciężarze. Każdy z nich robi to samo i posiada te same umiejętności, ale żaden nie może sam osiągnąc dającego mu satysfakcję celu.

Współpraca i współdziałanie prowadzą do tworzenia wewnętrznych więzi wśród członków grupy oraz rodzą poczucie tożsamości z zespołem, co zapewnia trwanie i sprawne funkcjonowanie zespołu na rzecz osiągania wspólnych celów jego członków.

Rywalizujące strony mają różne interesy, a więc występuje między nimi konflikt interesów. Można zatem powiedzieć o konkurujących ze sobą osobach, grupach czy organizacjach, że pozostają w konflikcie. Należy jednak zauważyć, iż konflikt i współpraca mogą istnieć jednocześnie! Przeciwieństwem współpracy nie jest konflikt, lecz brak współpracy. Na przykład mimo ostrego konfliktu interesów dwóch pracowników mogą oni ze sobą współpracować dla osiągnięcia pewnego celu, którego osiągnięcie przyniesie korzyść obu zainteresowanym; a z drugiej strony można przedstawić dwie organizacje społeczne, które mają wspólny cel (powiedzmy zbiórka pieniędzy na pewien szczytny cel) - nie występuje między nimi konflikt interesów, ale z takich czy innych względów nie potrafią one ze sobą współpracować.

Organizacje czy osoby, między którymi istnieje konflikt interesów, mogą się zintegrować we wspólnym działaniu, jeśli rozsądnie uznają, że dla obu stron lepiej będzie współpracować, niż osobno dążyć do wyznaczonych celów. Poprzez uzgodnienie zasad współpracy może także nastąpić wyznaczenie wspólnego celu, który będzie zadowalający dla obu stron. W uzgodnieniu strony konfliktu wspólnie starają się znaleźć najlepsze rozwiązanie ich problemu, zamiast dążyć do osiągnięcia zwycięstwa przez każdą ze stron. W innym przypadku, nawet bez uzgodnienia formalnej współpracy, dwie strony, między którymi istnieje konflikt interesów, mogą ze sobą współpracować, jeśli wymaga tego cel nadrzędny. Na przykład właściciele małych sklepów ostro ze sobą rywalizujących o klientów z osiedla potrafią spontanicznie wystąpić we wspólnym działaniu przeciw projektowi budowy na tym osiedlu supermarketu. Innym przykładem może być sytuacja, kiedy konkurujące ze sobą sklepy i restauracje zlokalizowane wokół miejskiego rynku tylko dzięki wzajemnej współpracy i współpracy z wymiarem sprawiedliwości mogą się uporać $\mathrm{z}$ gangiem ściągającym od nich haracze. Dzieje się to w myśl zasady, że wróg mojego wroga staje się moim przyjacielem. Najważniejszą zasadą w tym 
przypadku jest, aby cel nadrzędny zawierał w sobie poszczególne cele wszystkich skonfliktowanych stron, a wówczas można się spodziewać nie tylko skutecznego zaniechania konfliktu, ale także współpracy prowadzącej do pozytywnych zmian, tak dla każdego z zainteresowanych podmiotów, jak i dla całości organizacji, którą te podmioty mogą utworzyć.

Zadajmy sobie teraz pytanie: Czy firmy działające w tym samym sektorze rynku skazane są jedynie na alternatywę wykluczającą? Albo rywalizacja albo współpraca? Przecież w przyrodzie oba te zjawiska występują jednocześnie. Rywalizacja nie wyklucza współpracy, a współpraca nie wyklucza rywalizacji.

Nawet najostrzejsza rywalizacja państw czy innych jednostek terytorialnych lub plemiennych nie wykluczała czasowych czy nawet trwałych aliansów w realizacji wspólnych celów. Odkąd tylko istnieje w historii zjawisko podejmowania działalności gospodarczej, tak długo też obok rywalizacji poszczególnych podmiotów występowała i ich współpraca na różnych polach. Zatem zjawisko jednoczesnej rywalizacji i współpracy nie jest wcale zjawiskiem nowym. Dziś tylko - w dobie przybierającego na sile procesu globalizacji - zjawisko to przyjmuje nieco inne formy. Jak pokazują doświadczenia wielu organizacji, obok rywalizacji czy współpracy możliwa jest jeszcze trzecia droga - kooperencja (koopetycja).

\section{Kooperencja - znaczenie pojęcia oraz jego zastosowanie w realiach rynkowych}

Kooperencja to relacje między konkurentami, w których występują związki o charakterze ekonomicznym i pozaekonomicznym. Kooperencja jest definiowana jako jednoczesne występowanie relacji konkurencji i kooperacji między przedsiębiorstwami (np.: Lado, Boyd, Hanlon 1997 s. 110-141; Cygler 2009, s. 7). Mimo występowania elementów wspólnych należy odróżnić kwestie kooperencji od aliansów strategicznych. W przypadku kooperencji rozpatrywane są jednocześnie strumienie relacji współpracy i konkurencji między konkurentami, podczas gdy alians strategiczny jest jednostkowym aktem, umową i rozpatrywany głównie w kategoriach współpracy obejmuje znacznie węższą paletę form współdziałania.

- Kooperencja to dziarania podejmowane:

- $\quad$ dla wspólnego tworzenia wartości,

przy jednoczesnej konkurencji w podziale tej wartości,

w warunkach częściowej zbieżności celów.

Podstawowym powodem podejmowania współpracy przez konkurentów rynkowych jest zjawisko synergii. Zjawisko to odnosi się zarówno do współpracy odrębnych organizacji, jak i części składowych poszczególnych organizacji, a także do współpracy jednostek ludzkich na różnych polach ich działalności (współpracy sąsiedzkiej, sportowej, kulturalnej itd.). Efekty synergii uzyskiwane we współpracy, kooperacji, współdziałaniu wskazują na zalety wspólnego działania, wyrażone w zwiększonych efektach, tak całej współpracującej grupy, jak jej poszczególnych członków. Zwiększona efektywność wyraża się nie tylko poprzez zwiększenie korzyści na wyjściu, ale i poprzez zmniejszenie kosztów na wejściu. Relacja efektów do nakładów będzie bowiem korzystniejsza, gdy współpracująca 
grupa - dzięki wykorzystaniu specyficznych umiejętności jej poszczególnych członków - zużyje mniej materiałów, czasu, wysiłku intelektualnego itd. Gdy na przykład różne podmioty gospodarcze decydują się na współpracę, przynosi im to efekty $\mathrm{w}$ postaci zwiększonego zasięgu rynkowego, ale także redukuje koszty w dziedzinie badań czy rozwoju. Przy spełnieniu odpowiednich warunków:

odpowiedni dobór współpracujących stron,

zapewnienie stronom stosownego parytetu odpowiedzialności, korzyści

i uczestnictwa w podejmowaniu decyzji,

właściwe kierownictwo całości,

odpowiedni podział zadań,

synchronizacja działań - współpraca przynosi pożądany efekt synergiczny.

Trzeba też pamiętać, że podejmując decyzję o współpracy, podejmujemy najczęściej decyzję strategiczną, a więc odnoszącą się do efektów w odległym horyzoncie czasowym. Jeśli pod wpływem wymagań chwili podejmie się taką decyzję, to można wkrótce osiągnąć oczekiwany efekt synergiczny, ale w dalszej perspektywie uzyskać efekt ujemny. Jeśli na przykład firma podejmie współpracę z innym podmiotem, dzieląc się informacjami o rynku, posiadaną technologią itd., to po okresie obustronnych korzyści może przyjść moment, w którym współpracownik okaże się wzmocnionym i dobrze umocowanym na rynku konkurentem.

Zjawisko kooperencji jest coraz powszechniejsze. Wśród poszczególnych lekarzy czy też placówek medycznych (i to nie tylko na rynku komercyjnym) istnieje spora konkurencja, niemniej jednak muszą oni ze sobą współpracować dla dobra (zdrowia i zadowolenia) pacjenta, które z kolei przekłada się na wyniki finansowe (i opinię) całej służby zdrowia. Podobnie dzieje się na rynku reklamy. Poszczególne agencje na co dzień uwikłane w walkę konkurencyjną niejednokrotnie muszą dla zaspokojenia potrzeb klienta, a przede wszystkim dla własnego i wspólnego dobra, połączyć wysiłki, by zrealizować wielką kampanię reklamową. W takich przypadkach dochodzi często do wymieszania się poszczególnych zespołów, tworzenia grup złożonych z przedstawicieli różnych firm, tworzenia wspólnych projektów itd. Powszechnym dziś zjawiskiem jest konkurowanie połączone ze współpracą jednostek terytorialnych. Gminy lub miasta $\mathrm{z}$ danego regionu walczące o turystów czy inwestorów potrafią łączyć się w związki regionalne, wspólnie tworząc różnego typu programy.

Jak wynika choćby z powyższych przykładów, wiele podmiotów gospodarczych, jak i organizacji innego typu doszło do wniosku, że nawet na konkurencyjnym rynku, bez utraty własnej tożsamości i niezależności, można podejmować współpracę z rywalami rynkowymi, często dla osiągnięcia efektu synergicznego, a często po prostu dla uratowania swego miejsca na rynku. W czasach, kiedy mówi się nie tylko o konkurencji, a wręcz o hiperkonkurencji, kiedy wobec dominującej roli globalnych korporacji transnarodowych (KTN) zanikają możliwości konkurowania tradycyjnymi metodami, mniejszym podmiotom nie pozostaje nic innego jak połączenie swych wysiłków.

Tymczasem większość polskich drobnych przedsiębiorców woli rolę samotnych wilków. Wierzą, że dzięki swym umiejętnościom sami sobie dadzą radę na rynku, 
bez konieczności współpracy z kimkolwiek. Być może jest to wynikiem odreagowania na konieczność zrzeszania się w poprzednim systemie. Mała firma produkcyjna czy usługowa nie miała praktycznie możliwości działania na rynku, jeśli nie była członkiem spółdzielni rzemieślniczej. Toteż kiedy tylko zmiana systemu społeczno-politycznego umożliwiła swobodne gospodarowanie na wolnym rynku, polscy przedsiębiorcy gremialnie odrzucili wszelkie formy zinstytucjonalizowanej współpracy. A przecież wcale tak być nie musi, a wręcz nie powinno być. Współpraca ta jest jak najbardziej potrzebna. Najlepszym dowodem na to jest fakt, że w warunkach gospodarki rynkowej w Europie Zachodniej spółdzielczość rzemieślnicza funkcjonuje i są chętni do zrzeszania się, bo lepiej wspólnie przedstawiać ofertę, dbać o swe interesy, przeciwstawić się konkurencji. Spółdzielnia rzemieślnicza jest zatem jedną z form kooperencji, jak najbardziej odpowiednią dla drobnych przedsiębiorstw.

Inną formą kooperencji, w jaką mogą/powinny się angażować podmioty gospodarcze z sektora MŚP, są grupy producenckie. Pojęcie grupy producenckiej związane jest najczęściej z produkcją i przetwórstwem rolnym. Grupa producentów to luźna, nieprecyzyjna nazwa, która wskazuje tylko na fakt współpracy pewnej liczby podmiotów gospodarczych. Grupa taka nie ma osobowości prawnej. Aby się zarejestrować, musi przyjąc jaką́s formę prawną (np. spółdzielni, zrzeszenia). Formalna grupa producentów spełniająca dodatkowe warunki określone w ustawie o grupach producentów rolnych i ich związkach może uzyskać status grupy producentów w świetle ustawy i może zostać wpisana do rejestru grup producentów prowadzonego przez wojewodę. Formalna grupa sektora owoców i warzyw spełniająca wymogi ustawy może uzyskać status wstępnie uznanej grupy producentów lub uznanej organizacji producentów. Takim grupom przysługuje prawo do ubiegania się o pomoc finansową ze środków publicznych.

Doświadczenia spółdzielni, grup producenckich czy też różnego typu zrzeszeń, związków, stowarzyszeń przedsiębiorców, zarówno w kraju, jak i na całym świecie, wskazują, że kooperencja jest systemem bardzo pomocnym w prowadzeniu biznesu, szczególnie małego i średniego. Drobny przedsiębiorca, pozostając nadal samodzielnym w podejmowaniu wszelkich decyzji, mogąc czerpać satysfakcję z owoców własnej przedsiębiorczości w konkurencyjnej grze rynkowej, może jednocześnie czuć się pewniej w rywalizacji z dużymi firmami na globalnym rynku, poprzez współpracę $\mathrm{z}$ innymi przedsiębiorstwami, instytucjami samorządowymi czy też innymi organizacjami.

W systemie nowoczesnej gospodarki, gdzie produkcja i usługi wymagają intensywnego dopływu wiedzy, gospodarki opartej na niespotykanej do tej pory różnorodności form organizacyjnych, technologii i produktów, nadwyżka ekonomiczna musi być wytwarzana $\mathrm{w}$ inny sposób, który wymaga kooperacji przybierającej formę sieci gospodarczych (Domański, Marciniak 2003, s. 12). W.G. Nickels uważa, że przyszłością będą biznesy oparte właśnie na tworzeniu sieci. Podaje on taki układ, gdzie mała jednostka opiera swoją działalność na korzystaniu z usług innych podmiotów na zasadzie zleceń. Dla przykładu: w USA przyczyny nieefektywnych działań należy upatrywać w przestarzałych fabrykach, nadmiernie ostrożnym kierownictwie, niejasnej polityce rządowej oraz nieaktywnych związkach zawodo- 
wych. Stąd też zaleca się uatrakcyjnienie przedsiębiorstw na rynku światowym poprzez reindustrializację (Nickels 2000, s. 386-387).

\section{Częściowe wyniki badania dotyczącego współpracy małych przedsiębiorstw}

Badanie zostało przeprowadzone przez odpowiednio przeszkolone osoby metodą wywiadu bezpośredniego na grupie 185 małych przedsiębiorstw mieszczących się głównie w zachodniej Małopolsce (Częstochowa, Myszków, Zawiercie, Zagłębie Dąbrowskie) w grudniu 2016 roku. Przedsiębiorstwa te zostały dobrane w sposób przypadkowy i nie stanowią próby reprezentatywnej dla całej populacji polskich małych przedsiębiorstw. Niemniej jednak można na ich podstawie wyciągnąć pewne wnioski dotyczące skali zjawiska kooperencji w środowisku małych polskich firm. Choć - jak wspomniano - próba nie ma charakteru reprezentatywnego, to wyniki badania podano $\mathrm{w}$ skalach procentowych dla bardziej przejrzystego zobrazowania badanego zjawiska.

Jak pokazuje przeprowadzone badanie, jedna trzecia badanych nie prowadzi żadnej współpracy z firmami działającymi na konkurencyjnym rynku. Przy czym najczęściej (38\% - Rysunek 1) pojawiającym się motywem braku współpracy pomiędzy małymi firmami działającymi na tym samym (konkurencyjnym) rynku jest brak odczuwania potrzeby współpracowania z innymi firmami (konkurentami).

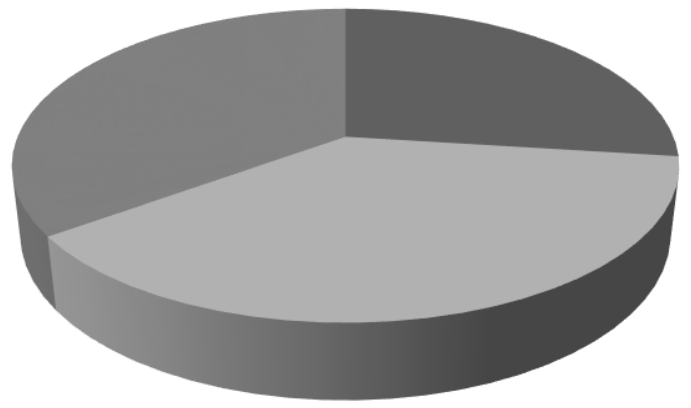

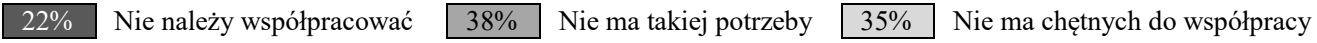

\section{Rysunek 1. Przyczyny braku wspólpracy}

Źródło: Opracowanie własne na podstawie wyników badania

Z kolei dość znaczna część przedsiębiorców jest zdania, że z konkurencją się walczy, a nie współpracuje. Jeden z badanych stwierdził nawet, że współpracy pomiędzy konkurującymi na rynku firmami zakazuje etyka biznesu. Zatem około $22 \% \mathrm{z}$ pośród badanych przedsiębiorców jest $\mathrm{w}$ większym czy mniejszym stopniu zdeklarowanymi przeciwnikami współpracy pomiędzy konkurującymi firmami.

Inną wymienianą przyczyną niepodejmowania współpracy pomiędzy konkurentami jest zgłaszany przez właścicieli małych przedsiębiorstw brak chętnych do takiej współpracy (35\% wskazań). Prawdopodobnie i w tej grupie znajduje się 
znaczna część przeciwników podejmowania współpracy, bo gdyby oni sami byli zwolennikami podjęcia współpracy, to zapewne znaleźliby chętnych do takich działań.

Jakkolwiek dwie trzecie spośród badanych deklaruje podejmowanie współpracy $\mathrm{z}$ innymi firmami działającymi na tym samym rynku, to jednak w większości jest to współpraca dość powierzchowna - ograniczająca się do pojedynczych przypadków pożyczania sprzętu, dokonywania wspólnych zakupów materiałów, informowania się o sytuacji rynkowej itp. Co piąty przedsiębiorca z grupy deklarujących współpracę z konkurencyjnymi przedsiębiorstwami (tj. około 14\% ogółu badanych) wskazywał na takie formy współpracy.

$\mathrm{Na}$ ściślejsze więzi pomiędzy konkurującymi firmami, takie jak np.: pomoc/wymiana technologiczna, sprzętowa, finansowa, wspólne przedsięwzięcia handlowe itd., wskazywałyby wypowiedzi niemal co trzeciego właściciela małego przedsiębiorstwa deklarującego współpracę (tj. około 19\% ogółu).

Zatem można przyjąć, że co trzeci $(19 \%+14 \%)$ spośród badanych właścicieli małego przedsiębiorstwa nawiązał mniej lub bardziej ścisłą współpracę z inną firmą na konkurencyjnym rynku.

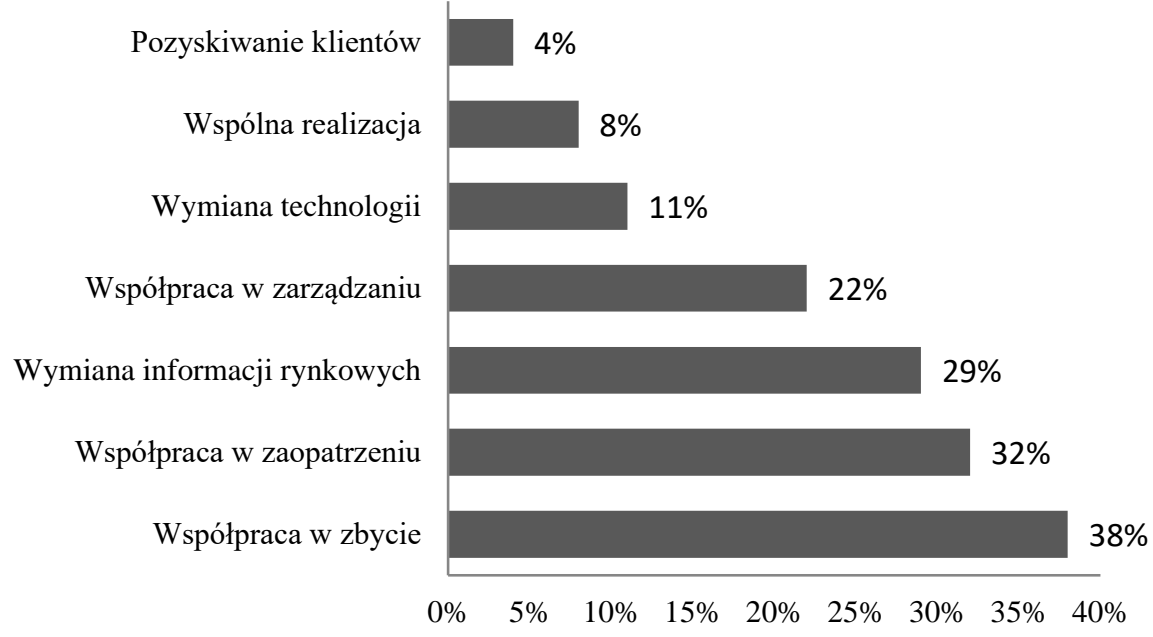

\section{Rysunek 2. Dziedziny wspólpracy konkurujących małych przedsiębiorstw}

Źródło: Opracowanie własne na podstawie wyników badania

Najczęściej podejmowaną (38\% ogółu badanych - Rysunek 2) przez konkurujące przedsiębiorstwa formą współpracy są wspólne działania w zakresie zbytu towarów i usług. $Z$ jednej strony może to nieco dziwić, jako że właśnie sprzedaż produktów jest najbardziej wrażliwa na konkurencję, ale $\mathrm{z}$ drugiej strony należy zauważyć, iż na trudnym rynku objętym globalną konkurencją jest to właśnie najtrudniejsza dziedzina działalności firm i dlatego przedsiębiorcy chętniej szukają tu sprzymierzeńców. Do tej liczby należałoby też dodać $4 \%$ deklaracji dotyczących wspólnego poszukiwania nowych klientów. Niemal co trzeci z badanych deklaro- 
wał współpracę w dziedzinie zaopatrzenia (32\%) oraz w wymianie informacji rynkowych $(29 \%)$, natomiast co piąty badany $(22 \%)$ dzielił się ze swymi konkurentami informacjami dotyczącymi sposobu zarządzania przedsiębiorstwem. Z kolei $11 \%$ badanych deklarowało współpracę $\mathrm{w}$ dziedzinie stosowanych technologii. $\mathrm{Z}$ jednej strony jest to niewielki odsetek badanych, ale $\mathrm{z}$ drugiej strony dotyczy on znacznej większości firm, gdzie taki czynnik może być brany pod uwagę (firmy produkcyjne, usługi budowlane, blacharstwo samochodowe itp.). Podobnie rzecz ma się $\mathrm{w}$ dziedzinie wspólnej realizacji projektów (8\%), gdzie taką współpracę deklarują głównie firmy budowlane oraz transportowe i firma telekomunikacyjna.

$\mathrm{W}$ realiach polskiego małego biznesu istnieje wiele powiązań rodzinnych. W identycznym lub podobnym segmencie rynku firmy prowadzą ojciec i syn, bracia, kuzyni lub co najmniej bliscy koledzy itp. Tymczasem wyniki badania pokazują, że w $80 \%$ przedsiębiorcy deklarujący współpracę z inną, konkurencyjną firmą są dla siebie ludźmi zupełnie obcymi, pozostali są dla siebie kolegami $12 \%$, a tylko $8 \%$ badanych deklaruje współpracę w ramach rodziny. I co ciekawe wśród badanych firm o powiązaniach rodzinnych nie ma ani jednej, którą wcześniej przypisano do firm ściśle współpracujących.

\section{Podsumowanie}

Przedyskutowane wcześniej zagadnienia dotyczące współpracy i kooperencji pozwalają wyciągnąć wniosek, jeśli nie o konieczności, to przynajmniej o pożyteczności stosowania zasad współpracy na konkurencyjnym rynku podlegającym prawom gospodarki globalnej. Współpraca ta jest też bardzo przydatna nawet pomiędzy firmami konkurującymi ze sobą w tym samym sektorze rynku, gdzie przyjmuje ona postać kooperencji. Szczególnie dotyczy to przedsiębiorstw małych i średnich, które w samotnej walce konkurencyjnej z gigantami rynkowymi z góry są skazane na niepowodzenie.

Jednak jak pokazuje przeprowadzone badanie, polscy właściciele małych przedsiębiorstw nie są do końca tego świadomi. Zresztą poza samą świadomością zasad gry na globalnym konkurencyjnym rynku przyczyn niepodejmowania współpracy $\mathrm{z}$ innymi firmami będącymi w podobnej sytuacji jest zapewne więcej. Celem badania nie było jednak poznanie tychże przyczyn.

Wyniki badania wskazują natomiast, że zaledwie jedna trzecia badanych firm podejmuje ze sobą ściślejszą współpracę $\mathrm{w}$ celu polepszenia swych szans $\mathrm{w}$ walce na trudnym konkurencyjnym rynku. Jedna trzecia badanych właścicieli małych firm podejmuje próby takiej współpracy (kooperencji). Natomiast pozostała jedna trzecia spośród badanych firm jest skazana na samotną walkę w ramach ostrej konkurencji rynkowej, gdyż ich właściciele nie uznają za słuszne podjęcia jakiejkolwiek współpracy wewnątrz swego segmentu rynku. 


\title{
Literatura
}

Chrzan E. (red.) (2011), Zarządzanie małym przedsiębiorstwem $w$ warunkach globalizacji gospodarki. Kooperencja, Sekcja Wydawnictw Wydziału Zarządzania Politechniki Częstochowskiej, Częstochowa.

Cygler J. (2009), Kooperencja przedsiębiorstw. Czynniki sektorowe i korporacyjne, Oficyna Wydawnicza SGH, Warszawa.

Domański R., Marciniak A. (2003), Sieciowe koncepcje gospodarki miast i regionów, KPZK PAN, Warszawa.

Kropotkin P. (2006), Pomoc wzajemna jako czynnik rozwoju, Oficyna Wydawnicza Bractwa Trojka, Poznań.

Lado A.A., Boyd N.G., Hanlon S.C. (1997), Competition, Cooperation, and the Search for

3. Economic Rents: A Syncretic Model, „Academy of Management Review”, Vol. 22, No. 1, s. $110-141$. DOI: $10.2307 / 259226$

4. Nickels W.G. (2000), Zrozumieć biznes, Dom Wydawniczy Bellona, Warszawa.

5. Panczykowski M. (b.r.), Ewolucja wspótpracy, czyli korzyści kontra konflikty, http://www.edunauka.pl/bioteocoop.php (dostęp: 05.12.2016).

\section{COOPETITION IN SMALL BUSSINES IN THE CONTEXT OF ECONOMIC GLOBALIZATION}

\begin{abstract}
The views that preach the natural superiority of competition over cooperation are supposed to be consistent with the theory of social Darwinism. Cooperation, or the ability to perform tasks collectively and solve problems together means the ability to create relationships and interact with others, the ability to work in a group to achieve common goals. In a modern economy, it is possible to compete and cooperate with enterprises operating in the same market sector, i.e. cooperation. In globalization, cooperation is particularly important for small enterprises.

The aim of this study is to indicate the possibilities of cooperation in a competitive market (coopetition) and specific scale of this phenomenon among Polish small enterprises. The survey shows that Polish entrepreneurs operating in the same (competitive) market sector are not particularly willing to cooperate.
\end{abstract}

Keywords: Coopetition, Globalization, Small Business 